\author{
Agnieszka Gawron \\ Katedra Teorii Literatury \\ Uniwersytet Łódzki \\ e-mail: agnieszka.gawron@uni.lodz.pl \\ ORCID: 0000-0001-8891-6563
}

\title{
Nie-miejsca jako przestrzenne wzorce kondycji podmiotu w Jak pokochać centra handlowe Natalii Fiedorczuk
}

Nagrodzoną Paszportem Polityki 2016 książkę Natalii Fiedorczuk Jak pokochać centra handlowe można uznać za część maternalnego nurtu literackiego, który coraz intensywniej rozwija się w Polsce $\mathrm{w}$ drugiej dekadzie XXI wieku. Tendencja ta, począwszy od lirycznej eseistyki Anny Nasiłowskiej w latach 90., przez interwencyjną, społecznie zaangażowaną intymistykę Manueli Gretkowskiej, w latach 2010-2016 przyjęła postać prawdziwego macierzyńskiego boomu w literaturze. W przeciągu kilku lat, w skali dotąd niespotykanej, powstawały fikcjonalne i niefikcjonalne narracje Justyny Bargielskiej (Obsoletki, 2010; Małe lisy, 2013), Sylwii Chutnik (Dzidzia, 2010; Mama ma zawsze rację, 2012), Joanny Woźniczko-Czeczott (Macierzyństwo non-fiction. Relacja z przewrotu domowego, 2012), Marka Susdorfa (Trzy śmiertelne historie. Cz. 1: Dziennik znaleziony w piekarniku, 2012), Aleksandry Michalak (Matka Sanepid, 2012), Małgorzaty Łukowiak (Projekt matka. Niepowieść, 2013), Joanny Mueller (Powlekać rosnące. Apokryfy prenatalne, 2013), Joanny Jagiełło (Hotel dla twoich rzeczy. O życiu, macierzyństwie i pisaniu, 2014) i wreszcie Natalii Fiedorczuk (Jak pokochać centra handlowe, 2016). Wymienione teksty łączy zarówno próba przedefiniowania ontologii macierzyństwa poprzez podkreślanie $\mathrm{w}$ - często introwertycznej - narracji tożsamościowego kryzysu, który wiąże się z wchodzeniem $w$ nową rolę, jak i dążenie do odsłonięcia sfer spychanych na margines społecznej świadomości, nieobecnych w kulturowych reprezen- 
tacjach tego doświadczenia. Główną bohaterką narracji matrifokalnych jest matka i jej narodziny jako bytu mówiącego i podmiotowego, zaś ważne tło problemów tożsamościowych stanowi zwykle krytyka społeczno-kulturowych norm promujących ponowoczesne wzorce intensywnego macierzyństwa oraz jego wyidealizowany, "lukrowany" obraz. Fiedorczuk podejmuje w swojej książce wszystkie wymienione wyżej wątki, jednak tym, co zdecydowanie wyróżnia jej prozę spośród podanych przykładów, jest poetyka spacjalna, określająca zarówno otwartą konstrukcję całej opowieści, jak i labilną kondycję samego podmiotu. Dlatego w niniejszym szkicu badam konstytutywną dla tekstu Fiedorczuk relację pomiędzy poetyką przestrzeni a konceptualizacją podmiotowości, związek kategorii przestrzennych z problematyką tożsamości i macierzyńskiego (depresyjnego) doświadczenia w kontekście teorii nie-miejsca Marca Augé oraz podmiotu jako nie-miejsca Ewy Rewers.

\section{Macierzyński podmiot jako nie-miejsce}

Pierwsze sygnały wskazujące, że mamy do czynienia z poetyką spacjalną znajdziemy już w inicjalnych paratekstach książki Fiedorczuk - tytule i motcie. Pojęciem kluczowym są tam definiowane za Markiem Augé, nie-miejsca, które - jak czytamy - „[...] są jednak miarą epoki [...] służąc[e] tak dziwnej komunikacji, że łączy ona jednostkę wyłącznie z innym obrazem jej samej"1. Nie-miejsca to - jak twierdzi francuski antropolog - przestrzenie anonimowe, których nie da się zdefiniować ani jako tożsamościowych, ani relacyjnych, ani historycznych ${ }^{2}$. Ich charakterystyczną cechą jest tranzytywność, z którą wiąże się przepływ, ruch, wieczne "teraz" i brak przynależności - i dotyczy to zarówno sfery terytorialnej, jak i emocjonalnej. Autorka konsekwentnie wykorzystuje kategorię nie-miejsca - buduje narrację, która wymyka się ujęciom tożsamościowym, zasadniczą rolę w procesie poznania i ukonstytuowania podmiotu odgrywają bowiem nie tyle praktyki tożsamościowe, co akty wyobraźni. To - jak pisze Rewers - wyobraźnia „umiejscowiona” w kulturze, języku, symbolicznym uniwersum i lokalnym słowniku, a jednocześnie „zdelokalizowana”, przekraczająca ich próg - jak nie-miejsce, w którym de-

\footnotetext{
1 N. Fiedorczuk, Jak pokochać centra handlowe, Warszawa 2016, s. 3. Dalej podaję numer strony bezpośrednio po cytacie.

2 M. Augé, Nie-miejsca. Wprowadzenie do antropologii hipernowoczesności, przeł. R. Chymkowski, Warszawa 2010, s. 53.
} 
cydującą rolę odgrywa samotność i podobieństwo ${ }^{3}$. Nie-miejsce funkcjonuje zatem w tekście Fiedorczuk jako metafora kondycji podmiotu, a jednocześnie pojęcie operacyjne, które pozwala na przeformułowanie kategorii macierzyńskiej podmiotowości w nowym języku ${ }^{4}$. Próby takich ontologicznych dookreśleń podejmowały wcześniej wyżej wymienione pisarki nurtu maternalnego. $\mathrm{W}$ ich tekstach dominują formuły tekstualne podkreślające graniczną, nietrwałą pozycję kobiety wchodzącej w macierzyństwo i związaną z tym konieczność podmiotowego odradzania się. Kondycję podmiotu określają tam metafory transformacji i pogranicza, jak metaxu, wylinka, metafora cebuli czy rozbudowywanego domu, w których, choć nie wprost, dostrzec jednak można charakterystyczną dla rytuału przejścia tranzytywność i liminalność macierzyńskiego doświadczenia. Tekst Fiedorczuk organizuje zasada sprzęgnięcia parametrów nie-miejsca jako właściwości środowiska (przestrzeni fizykalnej) z ontologicznym statusem podmiotu (przestrzenią mentalną protagonistki). W konsekwencji kategorie przestrzenne stają się podstawowymi parametrami rozumienia podmiotowości zarówno indywidualnej, tj. matki pogrążonej w depresji, jak i zbiorowej - odsyłają bowiem do uniwersalnych doświadczeń transformacji, również w wymiarze społecznym.

Na poziomie indywidualnym opowieść Fiedorczuk jest zakorzenioną autobiograficznie historią poporodowej depresji. Podmiotowy wzorzec reprezentacji tej choroby wykształcony został w klasycznym już opowiadaniu Charlotte Perkins Gilman Żółta tapeta z 1892 roku. W tej macierzyńskiej wersji feministycznego toposu "wariatki na strychu” ekwiwalentem choroby jest tytułowa żółta tapeta, symbol permanentnej kontroli i panoptycznej obserwacji. Związane z nią motywy uwięzienia, wyobcowania ze świata, niepanowania nad własnym życiem składają się na geografię emocjonalną Gilmanowskiego podmiotu. Fiedorczuk do pewnego stopnia powtarza feministyczne toposy zamknięcia w przestrzeni domowej, poczucie niezakorzenienia i osamotnienia ponowoczesnej, depresyjnej matki eksponuje jednak kładąc nacisk na figury ruchu i strategie ucieczkowe. Ruch, obok anonimowości i samotności, stanowi w tym przypadku jedną z trzech, nakładających się i podstawowych dla podmiotu jako nie-miejsca, figur.

Ruch i związana z nim organizacja przestrzenna strukturuje tekst Fiedorczuk już na poziomie kompozycyjnym. Poszczególne rozdziały, wyznaczające ślady na mapie psychicznych i życiowych doświadczeń bohaterki, odsyłają

3 E. Rewers, Więźniowie transkulturowej wyobraźni, w: Narracja i tożsamość (I). Narracje w kulturze, red. W. Bolecki, R. Nycz, Warszawa 2004, s. 49.

4 Zob. E. Rybicka, Geopoetyka. Przestrzeń i miejsce we wspótczesnych teoriach i praktykach literackich, Kraków 2014, s. 247. 
do, typowych dla wielkomiejskich przedmieść, nie-miejsc: to tytułowe centra, galerie i dyskonty handlowe (T., L., M., B. i P.), urzędy i przychodnie, podmiejskie składy materiałów budowlanych, drogi, stacje benzynowe i autostrady, a także przestrzeń wirtualna (fora i serwisy ogłoszeniowe). Codzienność protagonistki polega na takim ich praktykowaniu, w którym doświadcza ona siebie samej jako widza, ustanawiając jednocześnie dystans między sobą a spektaklem życia, w ramach którego sama dla siebie pozostaje najważniejszym widowiskiem:

Mój samochód jest tak brzydki, zardzewiały i urągający bezpieczeństwu, że nie warto kłopotać się nawet jego myciem. Zjeżdżam na pobliską stację benzynową i kupuję kawę w papierowym kubku. [...] Otwieram szeroko okno auta. Z przodu mam widok na parking dyskontu. Zapalam papierosa, ponieważ w drugiej dekadzie dwudziestego pierwszego wieku wciąż są kobiety, które palą, chociaż nie bez poczucia winy. Kolejne czterdzieści pięć minut, minut ukradzionych mężowi, dziecku, domowemu budżetowi, uważnym zakupom nieprzetworzonej żywności na ryneczku, minut ukradzionych swojemu zdrowiu, dentyście, fryzjerowi, minut skradzionych pracy, realizacji zlecenia, poszukiwaniom kolejnych, czterdzieści pięć minut, dwa tysiące siedemset sekund, które mogłabym poświęcić na bieganie, program odbudowy sylwetki z Ewą Chodakowską czy siłownię, upływa mi na tępym patrzeniu na parking dyskontu. Samochody przesuwają się po placu jak niezborne owady. $\mathrm{Z}$ aut wysiadają rodziny w sportowych kurtkach. Kobiety w eleganckich płaszczach i pełnym makijażu. Wąsy, brody, buty. Dzieci w adidasach. [...] Teraz dopijam ohydną kawę i wrzucam pusty kubek za fotel kierowcy. Przedmiot dołącza do swoich czterech niechlujnych kolegów z czterech poprzednich sobót. Z czymś w rodzaju półfizycznego bólu przekręcam kluczyk w stacyjce. Ciężko oderwać się od tych kilkudziesięciu ukradzionych minut. Kiedy w końcu udaje mi się zamknąć złośliwie wyskakujące okienka, muszę natychmiast przywrócić system do pełnej gotowości [s. 81].

Przyjemność podróżowania cechująca protagonistkę, nawet markowanie ruchu, jak można interpretować jej upodobanie do przesiadywania w samochodzie, oddaje potrzebę choćby chwilowego wyjścia z matczynej kondycji, która zawsze ma charakter relacyjny. Czas spędzony na parkingu to jednoczesne otwarcie na świat i strategia obronna, która zapewnia melancholijną przyjemność „wyjścia z interakcji”, z współprzeżywania. To całkowite zaprzeczenie specyfiki miejsca, polegającej na pełnieniu przez nie funkcji symbolicznie zamkniętego siedliska, w którym wykształcają się relacje społeczne. Pogrążona w depresji matka doświadcza rzeczywistości jak kierowca na autostradzie: omija wszystkie ważne punkty, do których się/nas zbliża, ale je komentuje, czerpiąc przyjemność ze zmiany perspektywy widzenia. Dokonujące się w ruchu przemieszczenia spojrzeń i obrazów, swoiste wydrążenie 
świadomości, jako jeden z przejawów depresji, ale też typowe dla hipernowoczesności, określa $\mathrm{w}$ tym przypadku nowoczesną formę anonimowości i samotności, związaną z pojawianiem się nie-miejsc. Najlepszym przykładem pierwszej postaci doświadczania nie-miejsca jest sieć internetowa, tworząca wrażenie "fałszywej familiarności". To tam, na rodzicielskich portalach i forach dyskusyjnych, wirtualne matki budują pozornie spójną społeczność, opartą na wspólnocie doświadczeń (podobieństwie), w rzeczywistości będącą jedynie rodzajem światów wyobrażonych, na które projektuje się fantazmaty o swoim idealnym życiu, by tym dotkliwszej krytyce poddać zachowania innych (pogłębiając tym samym własną i cudzą samotność). Internet jako summa nie-miejsc - funkcjonuje $\mathrm{w}$ tekście jako tranzytywna przestrzeń dyskursów, języków, kulturowych norm i oczekiwań, w której matki stają się - użyję określenia Rewers - więźniarkami transkulturowej wyobraźni ${ }^{5}$ :

Miejsca szybkiego ruchu, podobne do autostrad, dworców, centrów sprzedaży, znajdują się również w internecie. Do moich ulubionych, do których zaglądam jak do rozwibrowanego gniazda os, należą fora poświęcone wychowaniu dzieci i szeroko pojętemu życiu rodzinnemu. Wiele matek $\mathrm{z}$ tych forów ma prosperujące firmy i nie zdarza się im użyć wobec dzieci przemocy, krzyku, chociażby ze zwykłej desperacji. Ich mężowie są współczujący („,nie mam takich problemów w małżeństwie, ale chyba bym tak jak ty nie mogła"). Ich mężowie pracują ciężko i wytrwale, nie mają depresji, do dziecka wstawali od urodzenia. Regularnie i z pasją współżyją z żonami, ku obopólnej radości. Żony są zgrabne, a znów w sklepie $\mathrm{z}$ alkoholem proszono je o dowód. Wiem, że kłamią, wszyscy wiemy, że kłamią. Zastanawiam się, dlaczego i po co. I co jakiś czas ląduje tu kobieta niczym żołnierz w Normandii: opisuje swoją historię, nierzadko przejmujący opis samotności i niezrozumienia, a potem bezradnie rozgląda się po zgliszczach własnej wypowiedzi, której każdy aspekt rozkładany jest na czynniki pierwsze. [...] chociaż $\mathrm{w}$ dyskusji pod taką rozpaczliwą wypowiedzią pojawiają się posty wspierające i pomocne, to jednak decyduję, że te brutalne macierzyńskie awatary mogą mieć rację. Mówią, jak jest. Jesteś sama, nikt ci nie pomoże, ponosisz odpowiedzialność za swój stan. Tak się cieszę, że oblazły jak robaki kogoś innego, nie mnie. Obserwuję z ukrycia, z fascynacją, jak żują i wypluwają. Jest jak $\mathrm{w}$ damskiej szatni $\mathrm{u}$ baletnic, jak w mrowisku, do którego wpada ranne pisklę. „To nie ja, nie ja!” - chce mi się krzyczeć z radości i wczytuję się w słowa raniące, nieprzyjemne, soczyste. Po jakimś czasie zaczynam rozpoznawać po pseudonimach najbardziej jadowite awatary. Zastanawiam się, gdzie mieszkają i jak wyglądają w rzeczywistości. Są bowiem awatary neoliberalne, drapieżne, ale też awatary konserwatywne, sprzedające dziewiętnastowieczną prawdę o powinnościach kobiety w sreberku nowego rodzicielstwa [s. 124-125].

Najważniejszą jednak figurą podmiotowości są w książce Fiedorczuk tytułowe centra handlowe - ulubione nie-miejsce rozrywki młodych matek.

${ }^{5}$ E. Rewers, Więźniowie transkulturowej wyobraźni, s. 38. 
Centrum handlowe - wyznaje protagonistka - daje młodym matkom przyjazną namiastkę kontaktu ze światem, bez konieczności składania deklaracji, bez brania na siebie zobowiązań, bez przyjmowania stanowiska i przymusu wyrażania opinii [s. 36].

Galerie, podobnie jak autostrady i sieci internetowe, funkcjonują na zasadzie pewnej umowności, pozbawiając tego, kto w nią wkracza zwykłych uwarunkowań, uwalniają od relacji, tożsamości i społecznych wymogów są dla młodych matek substytutem psychicznej wolności, paradoksalnie budowanej na doznaniach typowych dla nie-miejsc, czyli samotności i podobieństwie. Jako bywalczyni centrów handlowych protagonistka doświadcza - jak pisał Augé - „realności swojego dysponowania chwilą” oraz autoidentyfikacji ${ }^{6}$, które wymykają się jej jako matce i jako podmiotowi pogrążonemu w depresji. Na drodze spotkania, identyfikacji i pracy wyobraźni bohaterka odnajduje siebie w innych; jak mówi: „one jak ja” - spragnione rozmowy z kimś poza własnymi dziećmi, targane poczuciem winy i wstydu, pozbawione poczucia kontroli nad własnym życiem, walczące z psychicznym bólem, który jest równie realny jak fizyczny, próbujące zbudować nową jakość w związku po narodzeniu dziecka, poddane nieustannej presji i ocenie społecznej, bez perspektyw na finansową stabilizację czy wsparcie państwa. Młode matki kolonizujące galerie handlowe nie są ponowoczesnymi flâneuse, ich „przyglądanie się" nie prowadzi do „czytania miasta”. Jest raczej - jak za Elisabeth Wilson przypomina Rewers - rodzajem window-shopping, zredukowanym do przyglądania się towarom, wystawom i sobie nawzajem ${ }^{7}$. Depresyjna narratorka identyfikuje się z tzw. "matkami gorszego sortu”, żyjącymi w poczuciu totalnego rozpadu i nieradzenia sobie z życiem, na które nie działa indywidualistyczna retoryka pracy nad sobą i obowiązek samokontroli, typowy dla ponowczesnych wzorców macierzyństwa, o czym gorzko, ale też autoironicznie pisze:

Pęcznieję od porad on-line i off-line. Każda z tych porad implikuje jednak podjęcie działania, do którego jestem chwilowo niezdolna. „Zatrudnij nianię [...]. Znajdź żłobek. Idź na fitness [...] idź na terapię, idź do psychiatry, do kołcza, do księdza, niech wypędzi z ciebie to niezadowolenie z siebie, niech dokona egzorcyzmu tłamszącego tęsknotę za szeroko otwartym oknem w samochodzie, za rozkoszą niemyślenia. Daj się szybko naprawić w warsztacie samochodowym dla zepsutych kobiet. Idź, idź i rób. Już” [s. 133].

${ }_{6}^{6}$ M. Augé, Nie-miejsca. Wprowadzenie do antropologii hipernowoczesności, s. 69.

7 E. Rewers, Język i przestrzeń w poststrukturalistycznej filozofii kultury, Poznań 1996, s. 106. 
Bohaterka Fiedorczuk obnaża fiasko postulatów kultury terapeutycznej, w której - jak twierdzi Eva Illouz - narracja radzenia sobie i samorealizacji $\mathrm{z}$ reguły jest narracją pamięci o cierpieniu ${ }^{8}$. Nie ma $\mathrm{w}$ niej miejsca na matkę depresyjną, jej stanu nie da się bowiem podporządkować określonemu zestawowi procedur zarządzania.

Warunkiem koniecznym „komunikacji” - podkreśla Illouz - jest, paradoksalnie, zawieszenie czyjegoś uwikłania w stosunek społeczny. Zakomunikować coś, to znaczy uwolnić się od swojej pozycji w konkretnym i szczegółowym stosunku i zająć stanowisko abstrakcyjnego mówcy potwierdzającego swoją autonomię lub swój punkt widzenia. Ostatecznie komunikowanie znaczy pozbywanie się lub branie $\mathrm{w}$ nawias emocjonalnej więzi, która łączy nas z innymi ${ }^{9}$.

Doświadczenia macierzyństwa, szczególnie w jego wymiarze depresyjnym, nie wpisuje się w ten postulat. Model kultury terapeutycznej, wyrastający z indywidualistycznej retoryki neoliberalizmu, definiowany jest bowiem w języku prawa i ekonomicznej wydajności, których nie daje się pogodzić z doświadczeniem, będącym - jak trafnie zauważyła Agnieszka Graff - „najgłębszą formą ludzkiej wspólnoty i zależności" ${ }^{10}$.

Mechanizmy kapitalizmu emocjonalnego odsłaniane są przez protagonistkę wieloaspektowo. Na pierwszym planie widzimy codzienne zmagania bohaterki z przygniatającą codziennością, zmęczenie i poczucie totalnego braku kontroli nad własnym życiem, którym towarzyszą rozpaczliwe próby sprostania wymaganiom stawianym młodym matkom $\mathrm{w}$ wymiarze emocjonalnym, opiekuńczym i zawodowym. W tym początkowym, najtrudniejszym okresie macierzyństwa kompulsywne sprzątanie (domu czy samochodu) jest jedynym aspektem życia, który daje poczucie panowania nad rzeczywistością:

Siedzę na kanapie, płacząc, z dzieckiem przy piersi. W pokoju lśni. Pachnie detergentem. Jest pięknie, jak w katalogu drogiej agencji nieruchomości. Ta kompulsywna czystość jest jedynym aspektem mojego życia, nad którym mam kontrolę. Nie mam kontroli nad ciałem, wliczając $\mathrm{w}$ to bolące jak skurwysyny piersi, ataki wilczego głodu w czasie karmienia i napawające trwogą, nieprzystające do żadnych kanonów kształty. Nie mam kontroli nad snem. Wydaje mi się, że nigdy już nic nie wymyślę, nie wyjdę poza to trwanie, to czekanie. Znajduję się w innej czasoprzestrzeni, w nieskazitelnie czystej celi o powierzchni 51,4 metra kwadratowego (nie licząc skosów). [...] Jednak jest to czas, kiedy w naszym domu jest najczyściej. Jest pięknie [s. 28].

8 E. Illouz, Uczucia w dobie kapitalizmu, przeł. Z. Simbierowicz, Warszawa 2010, s. 80.

9 Tamże, s. 58.

10 A. Graff, Rykoszetem. Rzecz o ptci, seksualności i narodzie, Warszawa 2008, s. 43. 
Rozmowa z psychiatrą, którą bohaterka odbywa po nasileniu objawów choroby, w sposób szczególny wydobywa koincydencję ekonomii, postępu i polityki zarządzania emocjami. Depresja jawi się tu jako świadectwo emocjonalnej niekompetencji bohaterki, którą można zniwelować po uiszczeniu właściwej kwoty za wizytę (200 zł) i leki (384 zł). Do tego otrzymuje się jeszcze bonus $\mathrm{w}$ postaci szczupłej sylwetki - jako efekt uboczny terapii.

Ironiczna rama, w jaką ujmuje się poważne sprawy, dotyczy również rozmaitych aspektów codzienności, w tym kwestii życiowych i macierzyńskich wyborów. Przykładowo zakup kosmetyków w znanej drogerii (R.) staje się metaforą przygniatającego ciężaru odpowiedzialności, a jednocześnie sugestią, że często wybór ów jest zwykłą iluzją. Szczególnie, że macierzyńska opowieść Fiedorczuk, choć pisana z pierwszoosobowej perspektywy, jest też uniwersalną opowieścią o pokoleniu prekariatu oraz wszystkich społecznie wykluczonych pozostających w stanie życiowego zatrzymania, w wiecznym teraz. Życie takich osób to "egzystencjalny bełt”, w którym się tkwi, kiedy traci się grunt pod nogami, to „niebezpiecznie rozbujane wiaderko, z którego nie wylewa się woda", które pokrywa się rzęsą, stęchłymi, tłustymi oczkami - okruchami codzienności:

bełtają w nim dzieci, mąż przesuwa je nogą za zasłonkę, kiedy przychodzą goście. Nie opowiadają o nim przyciszonym głosem matki na wychowawczym, nie opowiadają bezrobotni mężowie, całymi dniami wpatrzeni w telewizor, w ekran komputera z grą, nie opowiadają o nim nastolatki z nagła odkrywający ból istnienia mieszkający w bezruchu, w zastygnięciu, nie opowiadają ludzie starsi, na emeryturach i na rentach, osoby przesunięte niewidzialną, a gigantyczną ręką Boga i Historii na margines, osoby bezdomne. [...] Nie opowiadają o nim, bo im się nie chce, o tym się nie opowiada, bo nie wypada, w tym się po prostu tkwi [s. 133].

Pozostaje trwanie $\mathrm{w}$ bezczasie i poczucie niezakorzenienia typowe dla doświadczania nie-miejsc, symbolizujących kondycję kruchej i niepewnej egzystencji.

\section{Ciało jako element konstrukcji przestrzeni}

Pisząc o tożsamościowym kryzysie protagonistki nie sposób nie wspomnieć o roli ciała. „To ciało - jak pisze Rewers - pozwala bowiem umieścić podmiot zarówno $w$ przestrzeniach mentalnych, jak fizycznych, w czasie uniwersalnym i czasie bezpowrotnie upływającym, zakwestionować dy- 
stans dzielący podmiot od innych"11. Jeśli ciało, pojmowane współcześnie jako jedność umysłu i materii, przyjąć za podstawę wszystkich naszych aktów percepcji, to cielesność bohaterki w sposób kluczowy określa kondycję podmiotu jako nie-miejsca. W tym przypadku jest to o tyle ważne, że depresja poporodowa, jak żadna inna choroba o podłożu psychicznym, jest ściśle związana z doświadczeniem ciała. Jako abiektalne - bo związane z momentem przejścia - jest ono konsekwentnie wypierane z przestrzeni kultury, co dodatkowo wzmacnia tożsamościowe problemy bohaterki. W literaturze podejmującej problematykę depresji poporodowej ${ }^{12}$ występują matki wręcz wzorcowo wpisujące się w grupę ryzyka ze względu na cielesny (w tym okołoporodowy) ból i fizyczne zmęczenie, które towarzyszą im w tym okresie. Trudy ciąży, porodu, naturalnego karmienia, ból, wyczerpanie, brak snu nie tylko zamykają kobiety $\mathrm{w}$ cierpieniu, ale też pogłębiają wyobcowanie i rozpad tożsamości. Znamienne, że wspólnym doświadczeniem wszystkich depresyjnych matek, w tym bohaterki Jak pokochać centra handlowe, jest sposób, $\mathrm{w}$ jaki definiują one swoje ciało. To ciało anonimowe, podobnie jak świat zewnętrzny, opisywane z perspektywy świadka jego czynności, a jednocześnie obce, przejmujące nad matką władzę, intensyfikujące poczucie niepanowania nad własnym życiem. Ciało matki jest determinantą jej życia wewnętrznego i zewnętrznego, poczucia wstydu, zagubienia, oddzielenia od ",ja" i świata:

Niesamowite - pisze bohaterka książki Fiedorczuk - jak dużo postawnego i stanowczego miejsca zajmuje to ciało. Pozostaje w kontraście do poczucia znikania, które towarzyszy mi od pierwszej ciąży. Przestaję się fizycznie czuć, przestaję identyfikować zmęczenie, głód. [...] Stoję, schowana za lodówką, z ustami pełnymi czekolady. Wciąż wydaje mi się jednak, że kurczę się i zasuszam. Jest natomiast wręcz przeciwnie. Jest mnie bardzo dużo, to okropnie zawstydzające. Chciałabym być koścista i pokurczona, malutka, tak niewielka i nieważna, jak przed samą sobą się czuję. Bo przecież od ciała się zaczyna. Ciało stanowi reprezentację myśli i emocji, które nieumocowane dryfują pod sufitem, pod koronami drzew i pod daszkami zabudowań gospodarczych. Brak ciała jest antynamacalny. Mając ciało, należy się na coś zdecydować. Należy zadeklarować się, poczuć obecność [s. 75].

Język depresji jest w opowieści Fiedorczuk mową symptomów somatycznych: ciała kobiety, postrzeganego jako bezosobowe, nieokreślone, pulsujące

11 E. Rewers, Więźniowie transkulturowej wyobraźni, s. 47.

12 Zob. m.in. E. Albert, Od urodzenia, przeł. A. Weksej, Białystok 2016; D. Barker, Pęknięte odbicie, przeł. A. Kłosiewicz, Warszawa 2015; S. Holmes, Dziecko wspomnień, przeł. U. Gardner, Białystok 2016; E. Şafak, Czarne mleko. O pisaniu, macierzyństwie i wewnętrznym haremie, przeł. N. Wiśniewska, Kraków 2011; M. Susdorf, Trzy śmiertelne historie. Cz. 1: Dziennik znaleziony w piekarniku, Gdynia 2012. 
i rozmazane - zgodnie z dynamiką ruchu, który pozwala myśleć o zniesieniu granicy między wnętrzem a zewnętrzem. To „ciało" ujmowane w kategoriach przestrzennych, ciało, które stoi za lodówką, siedzi w samochodzie, które zajmuje zbyt dużo miejsca, nie mieści się w spodnie, ciało, które chciałoby się przykryć, schować, ciało wymykające się. „Moje ciało służy innym - wyznaje bohaterka - mimo że dzieci opuściły gościnne podwoje mojej macicy, [...]. Godzę się zatem z wizualną przemianą tego ciała i przez większość czasu zapominam, że je mam, bo go nie mam, nie jest moje, już nie jest moje" [s. 76].

Szczególną uwagę zwraca wymowa powiązanych z ciałem wrażeń sensorycznych, głównie audytywnych, olfaktorycznych i taktylnych, wskazujących na zaburzenia procesów tożsamościowych podmiotu. Wyobcowanie bohaterki podkreśla nieobecność zapachu, brak wrażliwości na dotyk oraz szorstka faktura skóry, którą często pokrywa zimny, nieprzyjemny pot. Nasilenie choroby sygnalizuje też sposób przyjmowania posiłków, w których nie czuje się smaku i zapachu, a jedzenie połyka się mechanicznie, kompulsywnie i bez przyjemności. W krajobrazie dźwiękowym dominuje cisza lub szum. O ile szum odsyła do charakterystycznych dla nie-miejsc figur nadmiaru i tranzytywności (podobnie zresztą, jak do audytywnej specyfiki domu, w którym bohaterka przebywa z dwójką dzieci), o tyle cisza wydaje się tu pełnić funkcję kategorii budującej ramy pamięci, odsyła do tego, o czym się nie mówi, co przykryte zostało wstydem. Powrót do zdrowia wiąże się z odzyskiwaniem wrażliwości sensorycznej i panowaniem nad ciałem, ale także i mową. Doskonale oddaje to zmiana, którą można dostrzec w tekście Fiedorczuk na poziomie leksykalnym: przechodzenie od nazw ogólnych, inicjałów (imion członków rodziny), przypominających reklamowe banery mijane na autostradzie, do nazw własnych, będących sygnałem otwarcia na świat, przynajmniej częściowego przełamania przez bohaterkę stanu wyobcowania.

\section{Praktyki wyobraźni i polityka pamięci}

W swojej pracy Maternal Encounters Lisa Baraitser pisała: aby dogłębnie pojąć istotę macierzyńskiej podmiotowości, należy postrzegać ją $\mathrm{w}$ kategoriach fundamentalnej zmiany, transformacji, nie prostej pracy pamięci ${ }^{13}$. Zmiana ta $\mathrm{w}$ sposób szczególny dotyczy sposobów doświadczania czasoprzestrzeni i jej związku z macierzyńską podmiotowością. Baraitser postuluje przesunięcie tradycyjnych ujęć tego doświadczenia wyłącznie $\mathrm{w}$ kon-

13 L. Baraitser, Maternal Encounters: The Ethics of Interruption, London 2009, s. 52. 
tekście sfery prywatnej, domowej, ku aktywnie eksplorowanej sferze publicznej, szczególnie zaś przestrzeni miejskiej. Jej zdaniem matka funkcjonuje $\mathrm{w}$ niej jako swego rodzaju freerunner ${ }^{14}$, przemierzający przestrzeń miejską wraz z fizycznym i mentalnym "obciążeniem” wynikającym z bycia matką. To ekwipunek dosłowny (staff), który zmusza kobietę do nowego spojrzenia na otaczającą ją przestrzeń, głównie pod kątem funkcjonalnym; ale to również, w sensie metaforycznym, egzystencjalno-kulturowy bagaż, z którym musi nauczyć się radzić sobie w nowej roli.

Jeszcze bardziej interesująca, a jednocześnie funkcjonalna w kontekście niniejszych rozważań, wydaje się zaproponowana przez Baraitser koncepcja macierzyńskiej podmiotowości. Jej podstawą jest kategoria przerwania/ zawieszenia/ interwału (interruption). Autorka definiuje ją jako momenty czasowego znikania (moments of undoing), wyjścia z własnej podmiotowości (off subject), po których podmiot powraca fundamentalnie zmieniony ${ }^{15}$. Ta umiejętność powrotu "do siebie" po radykalnej zmianie jest podstawą etycznego, osadzonego w codzienności projektu Baraitser.

Jak widać kategorii nie-miejsca nie da się oddzielić od figuracji temporalnych, podobnie zresztą - co podkreśla Augé - jak „miejsca i nie-miejsca, [które] mieszają się ze sobą i wzajemnie przenikają"16. Dlatego kondycją bohaterki targają nieustanne napięcia między potrzebą zadomowienia, oswojenia nowej roli, a potrzebą ciągłej zmiany, ruchu, pragnieniem wolności. Przywołane przeze mnie na wstępie przykłady narracji maternalnych wskazywały na podmiotowość płynną, graniczną, rodzącą się w linearnie przebiegającym procesie rekonstrukcji tożsamości, zakończonym podmiotową reintegracją. U bohaterki Fiedorczuk nie dochodzi do radykalnego, jednostronnego przełomu $\mathrm{w}$ postrzeganiu siebie jako matki. Co prawda zauważalne są ślady podmiotowej transgresji, o czym świadczą choćby liryczne tony odsłaniające skrywaną wcześniej miłość do dzieci, rozbijające ironiczną i surową narrację reporterską. Jednak nie ma tu miejsca na linearną ciągłość, dominuje raczej timless time (M. Castells), który zamyka drogę do postrzegania tej narracji jako tożsamościowej. Na przecięciu czasu linearnego (męskiego, obiektywnego) i cyklicznego (kobiecego) rozgrywają się Baraitserowskie interwały są one przestrzenią dla jednostkowej wyobraźni, która, choć na chwilę przywraca wolność i pomaga odzyskać właściwe miejsce, sama żadnego miejsca nie posiada ${ }^{17}$. W ujęciu Fiedorczuk, co znakomicie eksponuje zakończenie,

\footnotetext{
14 Tamże, s. 126.

15 Tamże, s. 81.

16 M. Augé, Nie-miejsca. Wprowadzenie do antropologii hipernowoczesności, s. 73.

17 E. Rewers, Więźniowie transkulturowej wyobraźni, s. 51.
} 
postrzeganie podmiotowości jako zamkniętej i esencjalistycznej jest niemożliwe. Istotą jej projektu narracyjnego, jako konstrukcji otwartej, jest bowiem eksponowanie podmiotowości matki jako nie-miejsca przepływu treści emocjonalnych, dyskursywnych, społecznych, kulturowych i wyobrażeniowych. To podmiotowość otwarta - na świat, na Innego, ale także na inne scenariusze życiowe poza macierzyństwem. Dlatego to emocjonalna, ucieleśniona prawda i pamięć o niej, stanowi o wartości tego tekstu pisanego jakby wbrew kulturowej, judeochrześcijańskiej tradycji, zgodnie z którą kobiety zobowiązane są do jak najszybszego zapomnienia o bólu wynikającym z macierzyńskiego doświadczenia. Bogactwo sensów naddanych implikowanych przez kategorię nie-miejsca, odsyłając do sfery emocjonalnej pokazuje też macierzyństwo jako nie-miejsce, w którym spotykają się uniwersalne i trudne doświadczenia wszystkich matek:

Jednak historia zawarta w książce nie jest moim świadectwem choroby. To wynik rozmów z kilkudziesięcioma osobami: kobietami, które doświadczyły depresji, które nigdy nie chciały się do niej przyznać [...]. Zdecydowałam, że nie chcę traktować tych historii osobno, chcę, by opowiedziane były jednym głosem, nawet gdybym musiała wziąć na siebie pytania czytelników i krytyków: „Czy naprawdę tak się czułaś?" [s. 148].

W wyniku tej strategii literatura staje się ważnym świadectwem emocjonalnej pamięci, refleksją nad tym, co indywidualne i zbiorowe, doświadczone i wyobrażone, prywatne i publiczne, wreszcie - co umiejscowione w centrum, a co - jak depresja poporodowa - na obrzeżach kultury symbolicznej.

\section{Bibliografia}

Augé Marc (2010), Nie-miejsca. Wprowadzenie do antropologii hipernowoczesności, przeł. R. Chymkowski, Warszawa: Wydawnictwo Naukowe PWN.

Baraitser Lisa (2009), Maternal Encounters: The Ethics of Interruption, London: Routledge.

Fiedorczuk Natalia (2016), Jak pokochać centra handlowe, Warszawa: Wydawnictwo Wielka Litera.

Graff Agnieszka (2008), Rykoszetem. Rzecz o płci, seksualności i narodzie, Warszawa: Wydawnictwo W.A.B.

Illouz Eva (2010), Uczucia w dobie kapitalizmu, przeł. Z. Simbierowicz, Warszawa: Oficyna Naukowa.

Rewers Ewa (1996), Język i przestrzeń w poststrukturalistycznej filozofii kultury, Wydawnictwo UAM, Poznań. 
Rewers Ewa (2004), Więźniowie transkulturowej wyobraźni, w: Narracja i tożsamość (I). Narracje w kulturze, red. W. Bolecki, R. Nycz, Warszawa: Wydawnictwo IBL PAN. Rybicka Elżbieta (2014), Geopoetyka. Przestrzeń i miejsce we wspótczesnych teoriach i praktykach literackich, Kraków: Universitas.

\section{Non-places as Spatial Paradigms of the Subject in Jak pokochać centra handlowe by Natalia Fiedorczuk \\ Summary}

The article is an attempt at reading Natalia Fiedorczuk's text (Jak pokochać centra handlowe [How to fall in love with shopping centers] in the perspective of Marc Augé's theory of non-places (non-lieux) and Ewa Rewers' concept of the subject as a non-place. The author uses the strategy in which attributes of non-place as a physical space are combined with the ontological status of the subject. It lets me define depressive condition of the mother as a transitive one, constituted on the figures of movement, anonymity and loneliness. This strategy also incorporates into maternity discourse the issues marginalized in cultural awareness (depression, emotion policy and maternal memory).

Keywords: literary space, maternal subject, postpartum depression, motherhood, literature 